Revista de Biología Marina y Oceanografía

Vol. 52, N²: 405-409, agosto 2017

DOI 10.4067/S0718-19572017000200020

\title{
RESEARCH Note \\ Spatial and bathymetric occurrence of Brama australis off the Chilean Coast and in the South Pacific Ocean
}

Ocurrencia espacial y batimétrica de Brama australis frente a las costas de Chile y el Océano Pacífico Sur

\author{
Marcelo A. San Martín ${ }^{1 *}$, Elson Leal $^{1 * *}$ y T. Mariella Canales ${ }^{2 * * *}$ \\ 'Departamento de Evaluación de Recursos, Instituto de Fomento Pesquero, Blanco 839, Valparaíso, Chile. *marcelo.sanmartin@ ifop.cl; \\ **elson.leal@ifop.cl \\ ${ }^{2}$ Center of Applied Ecology and Sustainability (CAPES), Pontificia Universidad Católica de Chile, Av. Alameda 340, Santiago, Chile. \\ ***mariella.canales@gmail.com
}

\begin{abstract}
Data about Brama australis distribution along the Chilean coast and the South Pacific is scarce and varied. The aim of this study was to provide new information concerning the spatial and bathymetric occurrence of B. australis in the Southern Pacific Ocean. To do this, all data and information available in scientific literature regarding Chile and the South Pacific Ocean were collected, including fishery dependent and independent as well as bycatch data. B. australis could be present in a wider latitudinal range from the $27^{\circ} \mathrm{S}$ to $57^{\circ} \mathrm{S}$, including fjords, open ocean, and along a band in the Pacific Ocean, from New Zealand up to the Chilean coast. Thus, B australis shows a wider distribution compared to previous studies especially towards the Southern Chile. Bathymetrically the species occurs with a higher frequency in depths between 100 and 250 m, however a low occurrence was recorded over $500 \mathrm{~m}$ depth. A potential association of B. australis with the West Wind Drift, which could influence the distribution of the species in the Pacific Ocean and off the Chilean coast, is hypothesized. Further work includes taxonomic studies to confirm the presence of the same species in the distributional area proposed here.
\end{abstract}

Key words: Brama australis, spatial distribution, Chile, South Pacific Ocean

\section{INTRODUCTION}

The species Brama australis (Valenciennes, 1838) is known in Chile with the common name of reineta, belonging to the family Bramidae. This species normally lives in tropical and temperate waters, within the epipelagic and mesopelagic zones (Thompson \& Russell 1996). According to Pavlov (1991), B. australis is widely distributed in the Pacific Ocean, although rather restricted to the circulation limits of the subtropical waters in the Southern Hemisphere $\left(27^{\circ} \mathrm{S}-48^{\circ} \mathrm{S}\right)$. It can also be found off the New Zealand coast (Horn et al. 2013).

In Chile, information about its spatial distribution is scarce and varied amongst authors. Pavéz et al. (1998), based on the distribution of a similar species of Bramidae, Brama japonica, and its main prey (Euphausia mucronata), argue that $B$. australis could exist between $20^{\circ} \mathrm{S}$ and $46^{\circ} \mathrm{S}$. Oyarzún (2001) points out that the species could be found from Coquimbo $\left(29^{\circ} \mathrm{S}\right)$ to Chile's southern coast. Reyes \& Hüne (2013) suggest a distribution between $27^{\circ} \mathrm{S}$ and $48^{\circ} \mathrm{S}$, and the Chilean Undersecretary of Fishing locates B. australis habitat from Chañaral $\left(26^{\circ} \mathrm{S}\right)$ to the Gulf of Penas $\left(49^{\circ} \mathrm{S}\right)$ (SUBPESCA 2009). From fishery viewpoint, the catches of artisanal fleet are localized mainly between Iloca and Guafo Island $\left(35^{\circ} \mathrm{S}-44^{\circ} \mathrm{S}\right)$, while in industrial fleet, they occur in the southern Chile, from Guafo Island to Gulf of Penas $\left(44^{\circ} \mathrm{S}-47^{\circ} \mathrm{S}\right)\left(\right.$ Gálvez et al. 2016) ${ }^{1}$. Thus, there exists neither unequivocal information on the general distribution of this species, nor any studies about its distribution off the Chilean coast.

Regarding the bathymetric distribution of B. australis, the literature indicates that Bramidae could inhabit depths of 400 to $500 \mathrm{~m}$ (Mead 1972, Last \& Baron 1994, Thompson \& Russell 1996). In Chile, Bahamonde (1977) registered the species between 100 and $500 \mathrm{~m}$, and the richest catches hauled B. australis from depths of 150 and $300 \mathrm{~m}$.

B. australis off the Chilean coast supports an important artisanal fishery with annual landings of about 25.000 tons, while the industrial fishery is still incipient, reaching landings of around 2.500 tons in the last year (SERNAPESCA 2016). From a fishery management perspective, the knowledge about the distribution of the species is important because it fosters understanding of the spatial structure of the species (Hutchings et al. 2007) and its interaction with fishing activity. Such understanding facilitates the

${ }^{1}$ Gálvez P, J Sateler, Z Young, R San Juan, J Olivares, K Belmar, E Garcés \& J González. 2016. Convenio de Desempeño 2015. Seguimiento de las Pesquerías Demersales y Aguas Profundas, 2015. Sección II: Pesquería Demersal Centro Sur, 2015. Subsecretaría de Economía y Empresas de Menor Tamaño, IFOP, 194 pp. 
enforcement of management rules that contribute to the sustainability of the fishery resource. Thus, this study aimed to collect all the information available in Chile about the spatial and bathymetric occurrence of B. australis off the Chilean coast. Data were gathered from the monitoring of the demersal fisheries in Chile where B. australis was a targeted as well as bycatch species. Also, data from demersal and pelagic surveys regarding the presence of $B$. australis was detected. In addition, the information about the presence of $B$. australis in the oceanic waters was used to produce a broad view on the distribution of this species in the South Pacific Ocean.

\section{Materials AND METHODS}

To study the presence of $B$. australis along the Chilean coast (18 $\left.21^{\prime} \mathrm{S}-57^{\circ} 00^{\prime} \mathrm{S}\right)$, three different sources were analyzed: survey data, commercial bycatch and target hauls. Data of $B$. australis in fishing hauls taken during acoustic surveys from 1993 to 2013 and off the Chilean coast (18 $8^{\circ} 56^{\prime}$ S-51 ${ }^{\circ} 00^{\prime} \mathrm{S}$ ) by the Instituto de Fomento Pesquero ${ }^{2}$ were used. The aim of the acoustic surveys was to estimate the abundance and biomass of different Chilean fishery resources (Table 1). In these surveys, fishing hauls are taking place to collect information about specific target species (anchovy Engraulis ringens, common sardine Strangomera bentincki, Chilean jack mackerel Trachurus murphyi, South Pacific hake Merluccius gayi, Patagonian grenadier Macruronus magellanicus, southern hake Merluccius australis and southern blue whiting Micromesistius australis) and its bycatch. Additional input came from logbook records of the fishing vessels from Central South Demersal Fishery ( $32^{\circ} 12^{\prime} \mathrm{S}$ $\left.43^{\circ} 43^{\prime} \mathrm{S}\right)$ and Southern Demersal Fishery ( $\left.36^{\circ} 06^{\prime} \mathrm{S}-57^{\circ} 00^{\prime} \mathrm{S}\right)$. This last information was collected by scientific observers aboard fishing vessels from 1997 to 2015. Most information corresponded to hauls targeted at other species, while a smaller amount was aimed to catch B. australis. Fishing hauls information from surveys, as well as those from the fishing vessels were taken by mid-water trawl and bottom trawl at different depths depending on the target species.

All hauls that registered B. australis as bycatch of other target species in the survey and fishery-dependent data, together with those where $B$. australis was a target species were selected. These fishing hauls carried information about location (latitude, longitude) and haul depth. The information was used to create a geographical map with the spatial location of all hauls where B. australis was registered. Besides, the occurrence of fishing hauls with $B$. australis at different depths was summarized in a histogram.

Table 1. Summary of B. australis records from different sources of information used in this study. Spatial coverage represents the boundaries with positive hauls of B. australis / Resumen de los registros de B. australis provenientes de las diferentes fuentes de información usadas en este estudio. La cobertura espacial representa los límites con lances positivos de B. australis

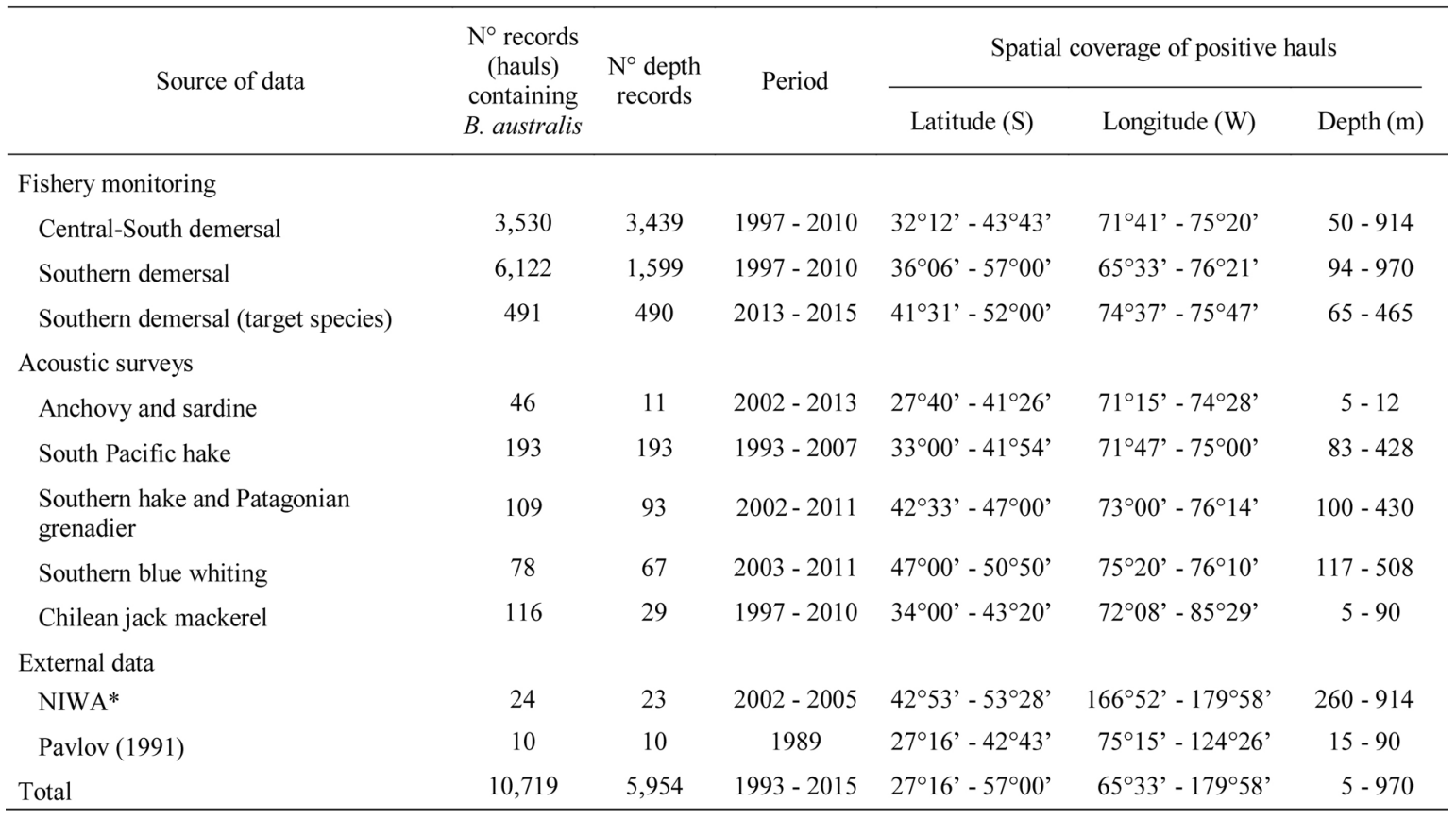

*Available at <http://www.fishbase.org/Map/OccurrenceMapList.php?id=54793\&genus=Brama\&species=australis $>$

${ }^{2}<$ www.ifop.cl $>$ 
The presence of B. australis in the South Pacific Ocean was inquired using information recorded in the formal literature (Pavlov 1991) and in the open access database of the National Institute of Water and Atmospheric Research (NIWA) ${ }^{3}$ of New Zealand between 2002 and 2005. In the former case, the fishing hauls were undertaken with mid-water trawls at depths of 15 to 90 m during 1989.

\section{RESULTS AND DISCUSSION}

The sources of data of the fishing hauls, which registered $B$. australis as bycatch and target species, are summarized in Table 1. A total of 10,719 positive records were used to create a map of the presence of the species off the Chilean coast (Fig. 1). Although acoustic survey data (anchovy and Chilean jack mackerel cruises) of northern Chile were analyzed, data reveal the occurrence of B. australis mainly until the $32^{\circ} \mathrm{S}$ (Fig. 1). The surveys taking place in lower latitudes in general did not register the species, except for one case that located it at $27^{\circ} \mathrm{S}$ near to coast. The same location was reported by Pavlov (1991). Information regarding the fishing hauls, with presence of $B$. australis around $40^{\circ} \mathrm{S}$ (Fig. 1) and with direction towards the open ocean, was taken from the surveys that assessed the Chilean jack mackerel biomass between 1993 and 2010. B. australis was reported by Pavlov (1991) in the same area that expands over the same latitude $\left(40^{\circ} \mathrm{S}\right)$ until $125^{\circ} \mathrm{W}$. The data collected from the Southern Demersal
Fisheries as bycatch verified the presence of the species towards the southern zone off Chile $\left(57^{\circ} \mathrm{S}\right)$ and close to the Argentinian border (Atlantic Ocean). The fishing hauls from the demersal fishery where $B$. australis was a target species attained between $41^{\circ} 30^{\prime} \mathrm{S}$ and $52^{\circ} 00^{\prime} \mathrm{S}$. Additionally, the acoustic surveys information shows that the specimens could also be found in the inland waters, fjords and channels of Southern Chilean coast (Fig. 1).

The number of records with bathymetric information used to describe the occurrence of $B$. australis was obtained from 5,464 hauls as bycatch and 490 as target (Table 1). A low number of records (128) showed presence of B. australis as bycatch at depths greater than $500 \mathrm{~m}$. Furthermore, these records corresponded to outliers in a box-and-whisker plot (not shown), thereby it was excluded from the histograms. Moreover, its presence at deeper than $500 \mathrm{~m}$ has only been reported in technical reports but not formal literature. Thus, bathymetrically over $98 \%$ of the records from hauls with $B$. australis as bycatch corresponded to catches from 50 to 500 $\mathrm{m}$ (Fig. 2a). The highest frequency of hauls registering $B$. australis were located between 100 and $250 \mathrm{~m}$, however also was observed over to $500 \mathrm{~m}$ on some fishing hauls too. Records of B. australis as a target species in the demersal fishery support the observation that the greatest presence of the species was in depths of 100 to $250 \mathrm{~m}$ (Fig. 2b).

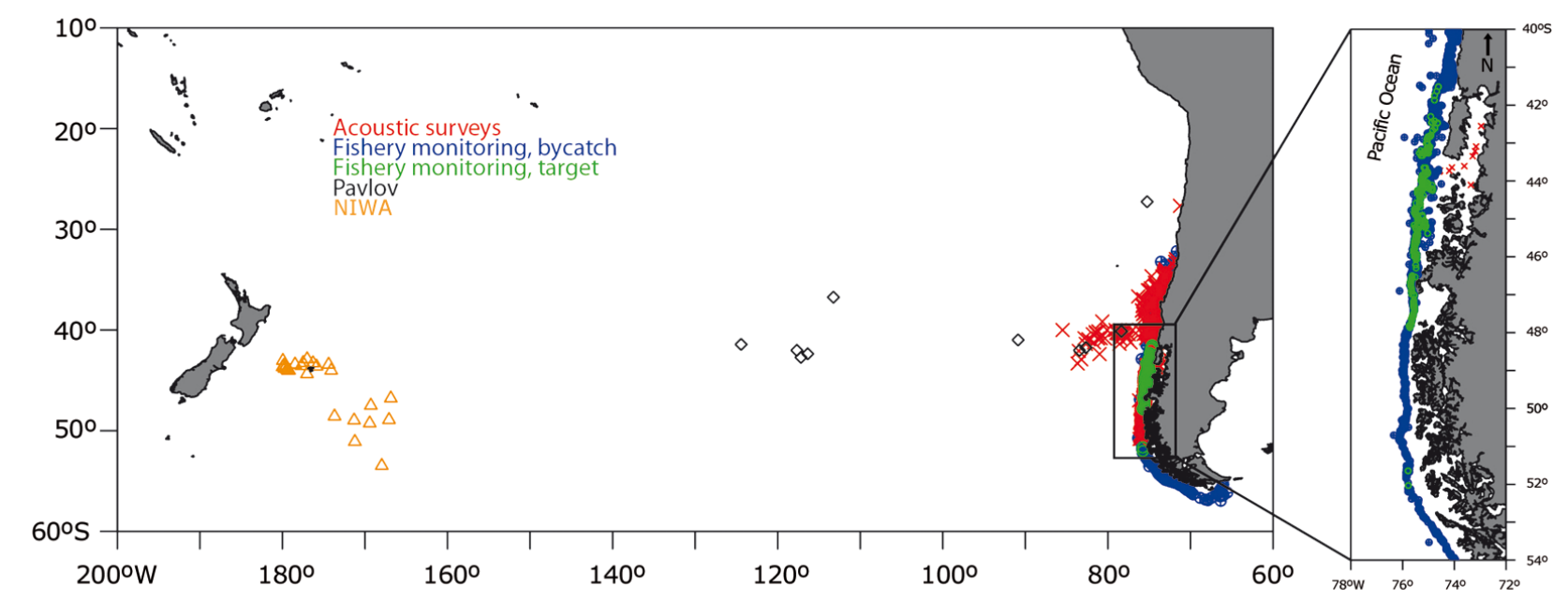

Figure 1. Distribution of the fishing hauls where B. australis registered a positive presence. Acoustic survey records (red cross), demersal fishery monitoring (bycatch: blue circles; target species: green circles). Records from Pavlov (1991) information (black diamond) and NIWA information (orange triangle). Zoom details are acoustic survey records in fjords (red cross), further fishery monitoring (bycatch and target) / Distribución de los lances con presencia de B. australis en las capturas. Registros en cruceros acústicos (cruces rojas), registros provenientes del monitoreo de las pesquerías demersales (captura incidental: círculos azules; especie objetivo: círculos verdes). Registros provenientes de Pavlov (1991) (diamantes negros) y NIWA (triángulos naranjos). En aumento el detalle de los registros presentes en los canales (cruces rojas) y aquellos provenientes del monitoreo de las pesquerías demersales (captura incidental y especie objetivo)

${ }^{3}$ NIWA, data available at <http://www.fishbase.org/Map/OccurrenceMapList.php?id=54793\&genus= Brama\&-species=australis> 


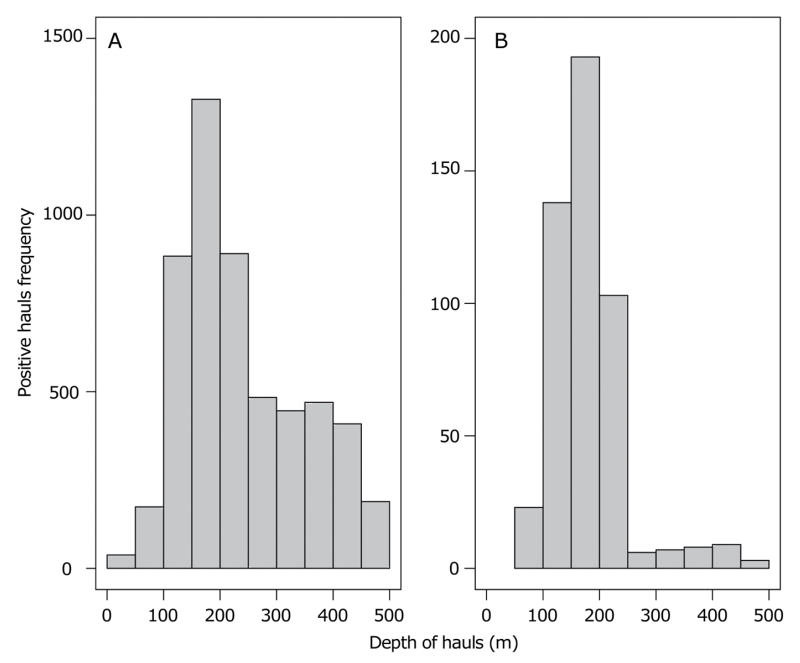

Figure 2. Frequency of the fishing hauls with a positive presence of $B$. australis regarding depth. Data correspond to records taken during the acoustic survey and the monitoring of demersal fishery $B$. australis as bycatch (A) and target hauls (B) / Frecuencia de lances de pesca con presencia de $\mathrm{B}$. australis respecto a la profundidad registrada. Los datos corresponden a registros tomados durante cruceros acústicos y el monitoreo de las pesquerías demersales, captura incidental (A), especie objetivo (B)

Results show that $B$. australis could be present in a wider latitudinal range compared to the one proposed by previous authors (Pavlov 1991, 1994; Reyes \& Hune 2013), particularly regarding its extension along the southern coast of Chile. A recent study supports these findings. It postulates that the feeding areas of B. australis off Chile would be located between $36^{\circ} \mathrm{S}$ and $47^{\circ} \mathrm{S}$, with potential spawning areas in oceanic waters $\left(80^{\circ} \mathrm{W}\right)$ (Ferrada et al. 2015). However, Torres et al. (2006) reported the species in the Gallegos River 51 $36^{\circ}$ 'S and $69^{\circ} 13^{\prime} \mathrm{W}$, and also on the Argentinian Southern platform around $46^{\circ} \mathrm{S}$ (Gorini \& Jaureguizar 2008).

From a taxonomic point of view, other species of the family Bramidae in Chile have been identified, therefore, some doubt that the findings shown here correspond all to the same species of B. australis still persists. Thus, the database of the National Aquatic Biodiversity Information System (NABIS) of New Zealand describes the species Xenobrama microlepis (Bramidae) as a species present off southern Chile and may be confused with B. australis. Besides, Nakamura (1986) and Pequeño (1989) described the species Brama dussumieri as part of the family Bramidae off the Chilean coast. However, recently Ferrada et al. (2015), through genetic analysis, reported one evolutionary unit and one stock of $B$. australis off the Chilean coast up to $55^{\circ} \mathrm{S}$.
On its bathymetric distribution, results sustain that the highest frequency of hauls registering $B$. australis occurred at depths of 100 to $250 \mathrm{~m}$, although hauls below $500 \mathrm{~m}$ also recorded the species. Crucially, most of the records used in this study corresponded to hauls where $B$. australis was not target species but bycatch. However, the few records with the species as a target of the fishery corroborate the result discussed above. Moreover, these findings agree with those of Gálvez et al. $(2015)^{4}$, who reported B. australis at depths of $150 \mathrm{~m}$ to 280 $\mathrm{m}$ in the fishing hauls where it was target species off Southern Chile $\left(42^{\circ} \mathrm{S}-47^{\circ} \mathrm{S}\right)$ in 2012 and 2014.

In spite of the spatial and temporal discontinuity of the samples, the records provided by Pavlov $(1991,1994)$ and NIWA, suggest that $B$. australis could be distributed along the Pacific Ocean $\left(65^{\circ}-185^{\circ} \mathrm{W}\right)$, and from the Northwest of New Zealand ( $\left.42^{\circ} 53^{\prime} \mathrm{S}-53^{\circ} 28^{\prime} \mathrm{S}\right)$ to the Chilean coast. In this work, the records of $B$. australis as bycatch show that the species may be found from $27^{\circ} \mathrm{S}$ to $57^{\circ} \mathrm{S}$, even in the inland waters of southern Chile. The findings here suggest a distribution pattern of the species similar to the one described for Chilean jack mackerel but in disagreement with its northern boundary. The records used here only detect the occurrence of $B$. australis until $27^{\circ} \mathrm{S}$, but the Chilean jack mackerel reaches latitude close to the Equator (Grechina 1998).

Thus, regarding the results obtained in this work, a potential association of $B$. australis with the West Wind Drift, which could influence the distribution of the species in the Pacific Ocean and off the Chilean coast is hypothesized. This is based in Pavlov (1994), who proposed a migratory pattern distributed in a broad area of the Southern Pacific Ocean. On the other hand, the records from NIWA indicate the presence of the species around New Zealand. Furthermore, the findings reported by Letelier et al. (2009) indicate that B. australis is part of the diet of Xiphias gladius in oceanic waters (over $80^{\circ} \mathrm{W}$ ) of the Pacific Ocean. In addition, these results reveal the occurrence of the species towards the southern area of the Chilean coast, and in fishing haul targeting Chilean jack mackerel in the open ocean and over the $85^{\circ} \mathrm{W}$.

Although the findings in this work provide a new vision about the potential distribution of B. australis off the Chilean coast and within the Southern Pacific Ocean, it is necessary to develop further studies. This involves that the bulk of information should arise as a target species, and clarify the existence of one or more species of the family Bramidae within the range of occurrence of $B$. australis proposed here.

${ }^{4}$ Gálvez P, J Sateler, K Belmar, Z Young, E Garcés, R San Juan, J Olivares, K Riquelme \& J González. 2015. Convenio I: Asesoría Integral para la pesca y acuicultura 2013. Proyecto 1.9: Programa Seguimiento de las Pesquerías Demersales y Aguas Profundas, 2013. Sección II: Demersales Centro Sur. Subsecretaría de Economía y Empresas de Menor Tamaño, IFOP, 150 pp. 


\section{ACKNOWLEGDEMENTS}

We are grateful to the technical staff of the Instituto de Fomento Pesquero (IFOP) that collected the field information. To Mr. Sergio Lillo and Mr. Patricio Gálvez, who supplied the data used in this work. Also, to Mr. Eladio Donoso for his comments. T. Mariella Canales is funded by the FONDECYT PostDoctoral Project 3160248.

\section{LITERATURE CITED}

Bahamonde R. 1977. Distribución y abundancia relativa de los principales recursos demersales entre Corral y Golfo de Penas. Investigación Pesquera 27: 1-46.

Ferrada S, C Canales, V Herrera, M Oliva, E Niklitschek, P Toledo, E Leal, C Carrasco \& M Pedraza. 2015. Origen natal y distribución geográfica de reineta en Chile. Universidad de Concepción. Facultad de Ciencias Naturales y Oceanográficas, Departamento de Oceanografía, Concepción. Informe Final, FIP N ${ }^{\circ}$ 2013-21:1-152. < http:// www.subpesca.cl/fipa/613/articles-89340_informe _final.pdf>

Gorini F \& A Jaureguizar. 2008. Asociaciones ícticas en la plataforma austral Argentina y su relación con los factores ambientales. Informe Técnico, INIDEP, Mar del Plata, 21 pp. <http://www.inidep.edu.ar/publicaciones/catalogo/ informes-tecnicos-2008/>

Grechina A. 1998. Historia de investigaciones y aspectos básicos de la ecología de jurel Trachurus symmetricus murphyi (Nichol) en altamar del Pacifico Sur. En: Arcos D (ed). Biología y ecología del jurel en aguas chilenas, pp. 1-36. Instituto de Investigación Pesquera, Talcahuano.

Horn P, J Forman \& M Dunn. 2013. Moon phase influences the diet of southern Ray's bream Brama australis. Journal of Fish Biology 82(4): 1376-1389.

Hutchings J, D Swain, S Rowe, J Eddington, P Puvanendran \& J Brown. 2007. Genetic variation in lifehistory reaction norms in a marine fish. Proceedings of the Royal Society of London B 27: 1693-1699.

Last P \& M Baron. 1994. Rays bream- a new pelagic fishery? Australian Fisheries 53: 19-22.

Letelier S, R Meléndez, E Carreño, S Lopez \& P Barría. 2009. Alimentación y relaciones tróficas del pez espada (Xiphias gladius Linnaeus, 1758), frente a Chile centronorte durante 2005. Latin American Journal of Aquatic Research 37(1): 107-119.
Mead G. 1972. Bramidae. Dana Report 81: 1-166.

Nakamura I. 1986. Important fishes trawled off Patagonia, 369 pp. Japan Marine Fishery Resource Research Center, Tokyo.

Oyarzún C. 2001. Catálogo de peces presentes en el sistema de corrientes de Humboldt frente a Chile Centro-Sur, 110 pp. Departamento de Oceanografía, Universidad de Concepción, Concepción.

Pavéz P, T Melo, H Ceriola, F Hurtado \& P Rasmussen. 1998. Análisis y evaluación de la pesquería de la reineta (Brama australis) en el litoral de la V Región. Universidad Católica de Valparaíso, Valparaíso, Informe Final, FIP N ${ }^{\circ}$ 1996-26: 1-125. < http://www.subpesca.cl/fipa/613/articles89564_informe_final.pdf>

Pavlov Y. 1991. Brama australis Valenciennes. A valid species of sea bream (Bramidae) from the Southeastern Pacific Ocean. Journal of Ichthyology 31(5): 6-9.

Pavlov Y. 1994. Data on ecology of southern Pomfret, Brama australis in the Southeastern Pacific Ocean. Journal of Ichthyology 34: 124-126.

Pequeño G. 1989. Peces de Chile. Lista sistemática revisada y comentada. Revista de Biología Marina 24: 1-132.

Reyes P \& B Hüne. 2013. Peces del sur de Chile, 497 pp. Editorial Ocho Libros, Valdivia.

SERNAPESCA. 2016. Anuario estadístico de pesca 2016. Servicio Nacional de Pesca, Valparaíso. <http:// www.sernapesca.cl>

SUBPESCA. 2009. Chile azul, Principales recursos pesqueros y de acuicultura, 133 pp. Subsecretaría de Pesca y Acuicultura, Valparaíso.

Thompson B \& S Russell. 1996. Pomfrets (Family Bramidae) of the Gulf of Mexico and nearby waters. Publicaciones Especiales del Instituto Español de Oceanografía 21: 185198.

Torres E, A Manero \& F Vargas. 2006. Listado sistemático y distribución temporal de los peces del estuario del río Gallegos (Santa Cruz, Argentina). Anales del Instituto de la Patagonia 34: 59-64.

Received 9 March 2017 and accepted 21 June 2017

Associate Editor: Mauricio Landaeta D. 